\title{
Антивирусная активность, накопление пролина и фенольных соединений в растениях картофеля при обработке биопрепара- тами
}

\author{
(c) Н.В. Балюк, Ж.Н. Калацкая, Н.А. Ламан
}

Государственное научное учреждение «Институт экспериментальной ботаники им. В.Ф. Купревича Национальной академии наук Беларуси»

220072, г. Минск, ул. Академическая 27, Беларусь

\section{E-mail: balyuck.natalya@yandex.ru}

Изучены особенности фрормирования антивирусной устойчивости картофеля при обработке биопрепаратами «Мультифаг», «Бактостим» и «Полибакт». Отмечено снижение степени заражения Y-вирусом на 20,5\% при опрыскивании листьев биопрепаратом «Мультифаг» в концентрации $2 \times 10^{7}$ КОЕ/мл, при этом содержание френольных соединений оставалось на уровне здоровых растений, а накопление пролина увеличилось на $25,5 \%$ по отношению к зараженным растениям.

Ключевые слова: антивирусная устойчивость, Ү вирус картофеля, Solanum tuberosum L., биопрепараты, пролин, фенольные соединения

В естественной среде обитания рост и развитие растений происходит в условиях постоянных изменений внешних фракторов, способных оказывать неблагоприятное воздействие на растительный организм. Существенные потери урожая и заметное снижение качества продукции картофеля связаны с заражением вирусами. Так, например, широко распространённый Ү вирус картофеля, может вызывать снижение урожайности культуры более чем на $50 \%[1,2]$.

Одним из путей экологически безопасного повышения устойчивости растений к неблагоприятным воздействиям является применение непатогенных ризосферных бактерий. Показано, что ростстимулирующие бактерии рода Bacillus и Pseudomonas индуцируют системную устойчивость растений к широкому кругу абиотических стрессоров, в том числе к засухе, засолению, тяжелым металлам [3], выявлены штаммы, проявляющие активность против бактериальных и грибных инфекций, однако в научной литературе недостаточно сведений о проявлении ими антивирусной активности, их влиянии на распространение и накопление вирусов в растительных тканях [4].

Цель данного исследования заключалась в изучении биохимических изменений и степени вирусного заражения растений картофеля при их обработке биопрепаратами белорусского производства, имеющих высокую антагонистическую активность к ряду фитопатогенов бактериальной природы.

Опыты проведены на микроклонально размноженных растениях картофеля сорта Бриз. Адаптацию растений-регенерантов осуществляли на почвогрунте на основе верхового торфа с добавлением элементов питания в виде минеральных солей. Адаптированные растения обрабатывали путем опрыскивания листовой поверхности биопрепаратами «Мультифраг» (вирионы Consortium Pseudomonas phages Pf-C, производство Институт микробиологии НАН Беларуси), «Бактостим» (споры и продукты метаболизма бактерий Bacillus amyloliquefaciens, производство Институт микробиологии НАН Бела- 
руси), «Полибакт» (2 штамма спорообразующих бактерий Bacillus amyloliquefaciens, штамм бактерий Pseudomonas brassicacearum, штамм азотфриксирующих бактерий Brevibacillus sp., штамм фоссратмобилизующих бактерий Bacillus megaterium) в концентрации $2 \times 10^{7}$ KОЕ/мл. Заражение вирусом ҮВК проводили путём натирания клеточным соком доноров растений картофреля при помощи мелкозернистой наждачной бумаги через 3 суток после обработки препаратами. Определение содержания пролина проводили по методу Bates c соавт. [5], накопление фотосинтетических пигментов определяли в 96\%-ном этиловом спирте по Lichtenthaler, K. [6]. Суммы френольных соединений определяли согласно методу [7], который основан на реакции фенолов с реактивом Фолина-Чокальтеу. Вирус ҮВК картофеля определяли с помощью иммуноферментного анализа (ИФА) согласно инструкции [8]. Пробы отбирали через 14 дней после инфицирования.

Обработка растений картофеля биопрепаратами «Полибакт» и «Бактостим» способствовала увеличению накопления ҮВК вируса в листьях на 20,4\% и 25,8\% соответственно по отношению к инфицированному контролю. При опрыскивании растений биопрепаратом «Мультифраг» наблюдалось снижение содержанию вируса на 20,5\% по отношению к зараженному контролю (рис. 1).

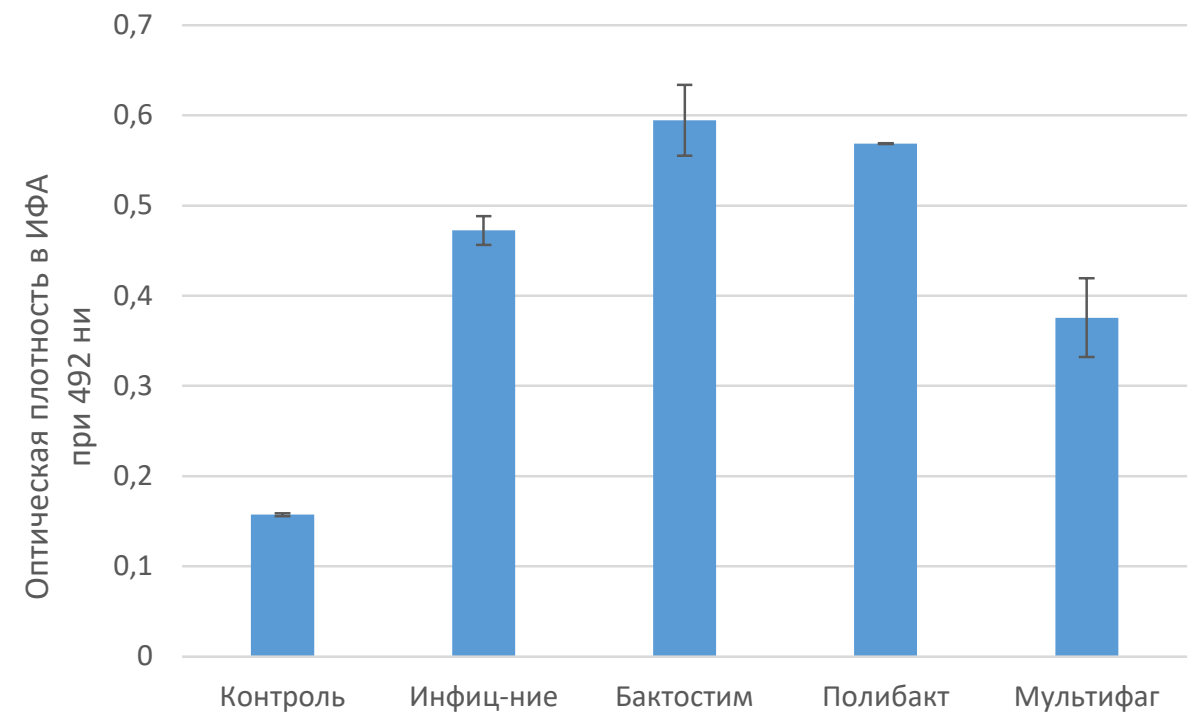

Рис. 1. Среднее значение оптической плотности в ИФА зараженных Ү-вирусом листьев растений картофеля при обработке биопрепаратами

Во всех исследуемых вариантах наблюдалось увеличение содержания фротосинтетических пигментов. Максимальных эффект наблюдался в инфицированных варианте (на $24,2 \%$ выше по отношению к неинфицированным растениям), что, вероятно, указывает на компенсационный эффрект ущерба, причиненного репликацией вируса в зараженных листьях [9]. Известно, что накопление френольных соединений является важным звеном фоормирования защитных реакций против патогенов [10, 11]. В зараженных растениях картофеля наблюдалось максимальное накопление фенольных соединений по сравнению с неинфицированным контролем. При обработке биопрепаратом «Бактостим» не отмечено достоверно значимых различий относительно инфицированных растений по содержанию фенольных соединений. Опрыскивание препаратами «Поли- 
бакт» и «Мультифаг» вызвали уменьшение содержания фенольных соединений на 17,0\% и 19,8\% по сравнению с зараженными растениями (рис.2 A).


Рис. 2. Содержание френольных соединений (А) и пролина (Б) в зараженных Y-вирусом листьях картофеля при обработке биопрепаратами

Экологические стрессы вызывают накопление пролина у самых разных видов [12, 13]. Вирусы являются важными модуляторами содержания аминокислот в инфицированных клетках, и метаболизм аминокислот имеет решающее значение в реакции растений на инфекцию. Например, в табаке уровни аланина, пролина повышаются как в листьях, инфицированных локально, так и в листьях с системной приобретенной устойчивостью к вирусу табачной мозаики [14]. В наших исследованиях не отмечено увеличения содержания пролина при инфицировании листьев Ү-вирусом картофеля. Максимальное увеличение пролина на $57,5 \%$ по сравнению с инфицированными контрольными растениями наблюдалось при применении препарата «Бактостим» на основе Bacillus amyloliquefaciens. Биопрепараты «Мультифраг» и «Полибакт» также способствовали повышению содержания пролина соответственно на 25,5\% и 20,1\% по отношению к инфицированным растениям.

Таким образом, при применении биопрепарата «Мультифаг» отмечено снижение степени заражения Ү-вирусом картофеля в листьях на 20,5\%, при этом содержание френольных соединений оставалось на уровне неинфицированных растений, а накопление пролина увеличилось на 25,5\% по отношению к инфицированным растениям. Опрыскивание листьев картофреля биопрепаратом «Бактостим» вызвало увеличение содержания вирусных частиц на 25,8\%. На фоне обработки биопрепаратом выявлено увеличение содержания пролина на $57,5 \%$ по сравнению с зараженными растениями. Для понимания полученных эффектов требуется проведение дополнительных исследований с расширением спектра биохимических показателей.

Выражаем благодарность сотрудникам РУП «НПЦ НАН Беларуси по картофрелеводству и плодоовощеводству» и Института микробиологии НАН Беларуси за предоставленный вирусный материал и биопрепараты. 


\section{Литература}

1. Анисимов Б.В., Белов Г. Л., Варицев Ю. А., Еланский Б. В. Защита картофеля от болезней, вредителей и сорняков. М.: Картофелевод. 2009. 272 с.

2. Макарова С.С., Макаров В.В., Тальянский М.Э Устойчивость картофеля к вирусам: современное состояние и перспективы // Вавиловский журнал генетики и селекции. 2017. T.21. №1. С.62-73.

3. Cherif H., Marasco R, Rolli E., Ferjani R., Fusi M., Soussi A., Mapelli F., Blilou I., Borin S., Boudabous A., Cherif A., Daffonchio D., Ouzari H. Oasis desert farming selects environmentspecific date palm root endophytic communities and cultivable bacteria that promote resistance to drought: oasis palm endophytes promote drought resistance // Environ. Microbiol. Rep. 2015. V.7. P.668-678.

4. Бурханова Г.Ф., Сорокань А.В., Черепанова Е.А., Сарварова Е.Р., Хайруллин Р.М., Максимов И.В. Эндофиитные бактерии Bacillus spp. с РНКазной активностью и устойчивость картофреля к вирусам / И. Максимов и др. // Вавиловский журнал генетики и селекции. 2019. Т.23. №7.

5. Bates L. S., Waldren R. P., Teare J. D. Rapid Determination of Free Proline for WaterStress Studies // Plant and Soil.1973. V.39. №1. P.205-207.

6. Lichtenthaler, K. and Welburn, A.R. Determination of Total Carotenoids and Chlorophylls A and B of Leaf Extracts in Different Solvents // Biochemical Society Transactions. 1983. V.11. P.591-592.

7. Singleton, V.L. and Rossi, J.A. Colorimetry of Total Phenolics with PhosphomolybdicPhosphotungstic Acid Reagent // Am. J. Enol. Viticult. 1965. V.16. P.144-158.

8. Инструкция по использованию иммуноферментного диагностического набора для определения вирусов картофреля / Рос. с.-х. акад. НПО по картофелеводству. М.: Коренево, 2016. 8c.

9. Ghobrial W. N., Ahlam A. Mehesen, Jehan M. Abass, Shalaby M. E, Omar A. F. Potential impacts of Rhizobium and compost tea enriched with Rhizobacteria for enhancing protection of fabae bean against Broad bean mottle virus (BBMV) // J. Agric. Res. Kafer EL-Sheikh. 2009. V.35. P.20-38.

10. Mondal, S. and Mitva, A. Reinforcement of cell wall in roots of Lycopersicon esculentum through induction of phenolic compounds and lignin by elicitors // Physiology and Molecular Plant Pathology, 2007. V.71. P.200-201.

11. Balogun O. S. and Teraoka T. Time-Course Analysis of the Accumulation of Phenols in Tomato Seedlings Infected with Potato Virus X and Tobacco mosaic virus // Biokem. 2004. V.16, №2. P.112-120.

12. Csonka L.N., Hanson A.D. Prokaryotic osmoregulation: genetics and physiology // Annul. Rev. Microbiol. 1991. V.45. P.569-606.

13. Dörffling K., Schulenburg S., Lesselih G., Dörffling H. Abscisic acid and proline levels in cold hardened winter wheat leaves in relation to variety e specific differences in freezing resistance // J. Agro. Crop Sci. 1990. V.165. P.230-239. 
14. Choi YH, Kim HK, Linthorst HJ, Hollander JG, Lefeber AW, Erkelens C, Nuzillard JM, Verpoorte R. NMR metabolomics to revisit the tobacco mosaic virus infection in Nicotiana tabacum leaves // J. Nat. Prod. 2006. V.69. P.742-748.

\section{Antiviral activity and accumulation of proline and phenolic compounds in potato plants treated with biologics}

${ }^{*}$ N. V. Baliuk, J. N. Kalatskaja, N. A. Laman

V. F. Kuprevich Institute of Experimental Botany of the National Academy of Sciences of Belarus

220072, Minsk, Akademicheskaya str. 27, Belarus

*E-mail: balyuck.natalya@yandex.ru

The features of the formation of potatoes antiviral resistance in conditions of treatment with "Multiphage", "Bactostim" and "Polybact" biologics were investigated. Observed was a 20.5\% decrease in the degree of $Y$-virus infection when spraying the leaves with a $2 \times 10^{7} \mathrm{CFU} / \mathrm{ml}$ "Multiphage" biologics. At that, the content of phenolic compounds remained at the healthy plants level, and the proline accumulation were increased by $25.5 \%$ comparing to infected plants.

Keywords: antiviral activity, Solanum tuberosum L., Y- potato virus, biologics, proline, phenolic compounds 